\title{
TTR
}

Traduction, terminologie, rédaction

\section{Vectors of Exchange: Translation Praxis in Cuadernos de Marcha and Revista Casa de las Américas}

\section{María Constanza Guzmán}

Volume 28, numéro 1-2, 1er semestre-2e semestre 2015

Territoires, histoires, mémoires

Territories, histories, memories

URI : https://id.erudit.org/iderudit/1041651ar

DOI : https://doi.org/10.7202/1041651ar

Aller au sommaire du numéro

Éditeur(s)

Association canadienne de traductologie

ISSN

0835-8443 (imprimé)

1708-2188 (numérique)

Découvrir la revue

Citer cet article

Guzmán, M. C. (2015). Vectors of Exchange: Translation Praxis in Cuadernos de Marcha and Revista Casa de las Américas. TTR, 28(1-2), 91-108.

https://doi.org/10.7202/1041651ar

\section{Résumé de l'article}

La traduction est depuis toujours au centre des projets intellectuels en Amérique latine et aux Caraïbes. Dans cet article, nous étudions les pratiques de traduction dans deux revues culturelles du $\mathrm{XX}^{\mathrm{e}}$ siècle de grande influence régionale et internationale : la revue uruguayenne Cuadernos de Marcha et la revue cubaine Revista Casa de las Américas. Cette étude s'intéresse aux pratiques de traduction de ces revues, et spécialement à la sélection des textes. Une analyse des compositions discursives qui résultent des pratiques de traduction nous permettra de déceler les vecteurs de l'échange intellectuel tels qu'ils se dévoilent dans les traductions. Nous analysons également les images que ces vecteurs créent des Amériques en tant que territoire tout en essayant de déterminer si ces images sont compatibles avec les pratiques des discours historiques qui contribuent à façonner les imaginaires régionaux existants ou, si au contraire, elles défient ces pratiques discursives. 


\title{
Vectors of Exchange: Translation Praxis in Cuadernos de Marcha and Revista Casa de las Américas
}

\author{
María Constanza Guzmán \\ Glendon College, York University
}

\begin{abstract}
Historically, translation has been at the core of intellectual projects in Latin America and the Caribbean. This article investigates the translation praxis of two influential twentieth-century Latin American and Caribbean cultural journals whose influence reached beyond their own national borders: the Uruguayan Cuadernos de Marcha and the Cuban Revista Casa de las Américas. This paper examines the translation practices of these periodicals focusing on the material selected for translation. Looking at the discursive compositions that are constructed through translation, it discusses the vectors of intellectual exchange as they can be traced via translation, the way in which these periodicals create images of the Americas as a territory, and the extent to which these images either conform to or challenge the historical discursive practices that contribute to shaping existing regional imaginaries.
\end{abstract}

Keywords: Latin America and the Caribbean, translation, Cuadernos de Marcha, Revista Casa de las Américas, translation praxis

Résumé

La traduction est depuis toujours au centre des projets intellectuels en Amérique latine et aux Caraibes. Dans cet article, nous étudions les pratiques de traduction dans deux revues culturelles du $\mathrm{XX}^{\mathrm{e}}$ siècle de grande influence régionale et internationale: la revue uruguayenne Cuadernos de Marcha et la revue cubaine Revista Casa de las Américas. Cette étude s'intéresse aux pratiques de traduction de ces revues, et spécialement à la sélection des textes. Une analyse des compositions discursives qui résultent des pratiques de traduction nous permettra de déceler les vecteurs de l'échange intellectuel tels qu'ils se dévoilent dans les traductions. Nous analysons également les images que ces vecteurs créent des Amériques en tant que territoire tout en essayant de déterminer si ces images sont compatibles avec les pratiques des discours historiques qui contribuent à façonner les imaginaires régionaux existants ou, si au contraire, elles défient ces pratiques discursives.

Mots-clés: Amérique latine et les Caraibes, traduction, Cuadernos de Marcha, Revista Casa de las Américas, pratiques de traduction 


\section{Tracing Latin American Cultural History via Translation}

When it comes to mapping the circulation and dissemination of ideas and the production of knowledge in the American continent, translation can be found at virtually every stage and discursive layer. Translation is a constant narrative practice-it was present before and during the conquest, and was crucial during the independence movements in Latin America. Throughout the twentieth century and to this day it has been a necessary condition for developing and shaping Latin American thought.

As sites of intellectual conversations, cultural journals provide a unique vantage point to study the circulation of ideas in a transnational and transcultural frame. This article investigates the relationship between translation and intellectual history in Latin America by looking at the translation practices of two influential Latin American journals that reached beyond their national borders: the Uruguayan Cuadernos de Marcha ["notebooks" of the weekly Marcha] and the Cuban Revista Casa de las Américas. ${ }^{1}$ The investigation is based on a comprehensive survey of all translated materials in each of the issues, charting which texts, from what languages and locations each journal translated and how these texts were framed, and how they related to other contents in the journal and to editorial decisions. These include the thematic patterns of translation praxis in each journal, the intersections between the narratives translated and other narratives and forms of discourse, and the presence and role of translation vis-à-vis the editorial policies and visions-stated and unstated - of the journals and of the larger intellectual project within which they are inscribed. Looking at the translation praxis and the discursive compositions that are constructed through translation, the central questions are: What are the vectors of exchange that realize themselves in these journals? What is the directionality of the translated exchanges? How are these exchanges "traducciones epidérmicas" [epidermic translations] - to use Angel Rama's term (1985, p. 9)-i.e., symptoms of deeper mental, political and symbolic workings? How does translation perpetuate colonial intellectual and epistemic legacies? How does it subvert, resist, decolonize the spaces inscribed by these legacies? What are the images of Latin America and the Caribbean that emerge from these journals?

1. This article is part of a larger project focusing on the translation praxis of twentieth-century cultural periodicals. A manuscript comprising detailed discussion of these and other journals is currently in preparation. 
This study has unfolded on the basis of an interdisciplinary framework which includes mainly contemporary translation and literary studies, and Latin American cultural theory. Methodologically, the project has involved extensive library research. Epistemologically, the approach to the materials is part of a view of translation as part of the Latin American archive and its relation with narrative and cultural history. ${ }^{2}$ The project does not aim to provide a large, comprehensive historical account; rather, it has elements of a microhistory, in the sense that it looks at small bits of experience and at the little facts of history. It is premised on the observation that translation, as a practice and as part of Latin American intellectual history, has been relatively unexamined; thus, investigating the intersections between translation and intellectual history in the Americas helps reveal "subjugated knowledges," whether lesser known facts, understudied practices or unheard voices. ${ }^{3}$ As such, translation praxis is part of the configuration of a genealogy of translation in its relation to Latin American intellectual history.

The project has an ethnographic impulse, in the sense that it involves not only the materials in the archive but also the cultural practices that can be traced through archives. In other words, inasmuch as translated products are traces of translation praxis, they serve to reconstruct aspects of the practice and of its agents; translation praxis "sheds light on the material and symbolic conditions of the production and reterritorialization of narratives, the formation of canons, and the discursive construction of global collective images" (Guzmán, 2013b, p. 173). ${ }^{4}$ Cultural journals can be sites of exchange, and often constitute "contact zones" in that they are "spaces where peoples geographically and historically

2. This view of narrative practice as related to the Latin American archive is informed by Roberto González Echevarría's Myth and Archive: A Theory of Latin American Narrative.

3. Foucault talks about "subjugated knowledges" as "a whole set of knowledges that have been disqualified as inadequate to their task or insufficiently elaborated: naive knowledges, located low down on the hierarchy..." (1980, p. 82).

4. This aspect of the project is also derived from an earlier article entitled "Translation North and South: Composing the Translator's Archive," which proposes, based on Michel Foucault's notion of the "archive", the notion of the "translator's archive"; it is informed by the work of translation scholars Hélène Buzelin, Daniel Simeoni, and Joshua M. Price. 
separated come into contact with each other and establish ongoing relations," which may be unequal or asymmetrical (Pratt, 1992, p. 6). As cultural products in the contact zone, cultural journals embody cultural history and are, thus, privileged sites to shed light on society's movements and its pulse.

Regarding Latin American cultural theory, the analysis is inspired by the work of Uruguayan scholar Ángel Rama, particularly by the notions he posits for narrative analysis in $L a$ transculturación narrativa en América Latina, namely "selectividad" "concentración" and "reiteración" ${ }^{5}$ as a framework to view narratives in terms of cultural contact, specifically in asymmetric relations of coloniality (1985, pp. 194-195). ${ }^{6}$ These notions provide criteria to read the translation praxis in these journals focusing on specific aspects of the selection of translated materials, and also to view the translations within their larger discursive compositions. This perspective enables sharper analysis particularly of what I have termed the translation density in each journal, i.e., the presencein quantity and intensity - of specific issues, themes, authors, and other aspects of narrative practice and circulation - in and through translation.

Historically, intellectual projects in Latin America and the Caribbean have frequently been founded on and nourished by translated narratives; translation has been an ongoing practice in Latin American journals, ${ }^{7}$ in the pages of many of which, very often,

5. For this article I used the Spanish version of Rama's book, entitled $L a$ transculturación narrativa en América Latina (1985). This seminal work of Latin American literary and cultural criticism was recently translated into English and published as Writing across Cultures: Narrative Transculturation in Latin America (2012).

6. I elaborate on Ángel Rama's work and its relationship with understanding translation as an experience of the Americas in the article "Ángel Rama y la traducción como praxis y experiencia americana” (Guzmán, 2013a).

7. A considerable amount of cultural historiography has been devoted to Latin American periodicals, and important recent works provided a critical revisiting of the role these played in Latin America in the twentieth century. This research has been informed by the works of Beatriz Sarlo (1999), Regina Crespo (2010), Raúl Sosnowski (1999), Lydia Elizalde (2008, 2010), and others. Among several works by scholars who have done research projects, including case studies, on translation and specific periodicals, Patricia Willson's book on the Argentine Sur (2004) has been the most influential for this study. 
there is a considerable volume of translated content. Nevertheless, translation may not have been a fully reflective practice, inasmuch as it is the enactment of perspectives that view the importation of foreign ideas as the ideal, and translated material "from abroad" as a form of intellectual production that enjoys higher prestige than the production of local knowledge. As Aníbal Quijano points out,

after the colonization of America and the expansion of European colonialism to the rest of the world, the subsequent constitution of Europe as a new $i d$-entity needed the elaboration of a Eurocentric perspective of knowledge $[\ldots]$ a new way of legitimizing the already old ideas and practices of relations of superiority/inferiority between dominant and dominated. (2000, p. 534)

Quijano notes that this entailed a process of "incorporation" of diverse and heterogeneous cultural histories into a single order dominated by Europe and

a cultural and intellectual intersubjective configuration equivalent to the articulation of all forms of labor control around capital, a configuration that established world capitalism. In effect, all of the experiences, histories, resources, and cultural products ended up in one global cultural order revolving around European or Western hegemony. Europe's hegemony over the new model of global power concentrated all forms of the control of subjectivity, culture, and especially knowledge and the production of knowledge under its hegemony. (2000, p. 540)

This is the legacy that Ángel Rama traces in La ciudad letrada [The Lettered City], as he unveils the filial connection between colonial discourse and intellectual production-even as colonial discourse becomes secularized in the form of Western knowledge and moves toward "modernity". As Lydia Liu puts it, translation has been part of two parallel historical developments:

First, translation has been indispensable to the processes of global circulation of colonial language theories, universal history, scientific discourse, material culture, and internationallaw for the past hundred years. Second, colonial encounters between European and "other" languages have helped define the unique intellectual contour of Western philosophical thinking about language, difference, culture, and alterity. (1999, p. 3) 
When it comes to translation, if and when translation is a way of privileging Western frameworks and voices from the (euro)centre, translation praxis is consistent with the Eurocentric logic of the coloniality of knowledge.

A productive tension emerges, thus, when cultural journals have as a stated goal and vision that of being "Latin American", as when it comes to their translation practice the question arises: How is translation practiced as part of the goal of creating or imagining Latin America? How is the journal, in its contents, its translation and its general narrative practices, supporting its Latin American ideal? Does the journal implicitly or explicitly rely on an idea of Latin America formed by European and/or Eurocentric views?

Marcha and Revista Casa stand out among others in part because both aimed to cover a Latin American scope and posited the question of Latin American knowledge and identity from the start. The journals' explicit focus on Latin America implied that the editorial vision was committed, in one way or another, to a sense of intellectual autonomy and self-determination, while aspiring not to restrict their project to the national scope but, rather, to contribute to the Latin American cultural field. These cases exemplify the way this tension operates in each journal and the role translation plays in journals that unfold within the contours of specific territorial imaginaries and, in turn, contribute to produce them. Building on the more general questions posited earlier, an added set of questions may be asked specifically of Marcha and Casa: While positioning themselves as Latin American intellectual fora, are these journals, in their narrative practices, affirming of Latin American intellectual production, or do they still respond to a unidirectional logic of Eurocentric intellectual relations that privileges dominant Western discourses? ${ }^{8}$ Or, conversely, are these journals able to establish a transcultural interaction of cultural production which, rather than premised on the absolute superimposition of dominant discourse, achieves a complex, bi/multi-directional cultural organicity, a poiesis americana [a poiesis of the Americas], leading to transcultural forms of intellectual exchange and vernacular ways of knowing?

In order to thematize the translation praxis of each journal, I have used as a starting point the way the journals frame their own intellectual position and editorial vision, to then look at

8. This topic of the intellectual legacy of the letrado [or man of letters] as a colonial one is discussed throughout Rama's The Lettered City (1986). 
the interplay between their vision and its translation practice. Although admittedly intertwined with their corresponding political fields, these journals as projects are related to society at large, in its heterogeneous and layered complexity, and are thus not reducible to the discursive articulations of dominant national political discourses. I intend to offer a narrative, or rather, a relato of previously understudied translation cases, aiming to bring translation to the surface and suggest points of convergence among them and between editorial projects and other forms of discourse.

\section{Translation in and for Latin America: Marcha and Casa de las Américas}

Both the Cuban Casa de las Américas (1960-present) and the Uruguayan Cuadernos de Marcha (primera época [first period] from 1967 to 1974), are among the most influential Latin American cultural periodicals of the twentieth century; particularly in the sixties and seventies, they had a strong presence in the Latin American field beyond the national borders where they were produced. As Jean Franco explains, Revista Casa was widely distributed, even "in defiance of the censorship that prevailed in many Latin American countries":

Casa de las Américas celebrated the liberation struggles of the Third World [...] and the tradition of Latin American anti-imperialism epitomized by Martí. It awarded literary prizes in the categories of the novel, poetry, the essay and the short story, which were then published and distributed throughout Latin America. Attractively illustrated, Casa de las Américas responded to the long-standing dream of the avant-garde to close the gap between life and art and to foster intellectual commitment to the cause of emancipation [...] It represented a new cultural geography, one whose center had drastically shifted from Europe. (2002, p. 45)

Similarly, Marcha, was a referent for the Latin American left, part of the formation of a "Latin American consciousness" (as Peirano argues throughout her 2001 study). As Mabel Moraña describes it in her introduction to a collection of essays devoted to Marcha, it constituted a paradigmatic case, a model of creative and critical production which, although having emerged in one of the smallest and most peripheral Latin American countries, quickly projected itself beyond cultural and ideological borders to establish a transnational dialogue (2003, p. 9). Significant differences aside, 
and even though each of these two journals was strongly rooted in its own national context, Revista Casa and Marcha both reached beyond their borders and covered a large span of the Latin American cultural field. This was a stated goal, a Latin American one, of both journals from the time they were founded. It was part of a vision, and also an effect, at least in part, of their scope and range of influence.

Revista Casa and Marcha were active and arguably at the centre of Latin American intellectual foment throughout the sixties and seventies, years of major political changes and heated cultural debates in Latin America. Moreover, contrary to other cultural journals at the time, both had an overtly antihegemonic and antiimperialist vision. Did they consider translation as part of the narrative praxis through which they would advance their cultural project and develop their idea of Latin America?' Given their anti-imperialist thrust, did they resist translation? To what extent was translation part of their intellectual and political agendas? What would be the role and position of translators within these projects? How, through what strategies, was translation to be practiced? ${ }^{10}$

\section{Translation in Revista Casa de las Américas}

Founded in 1959, Casa de las Américas is an important cultural institution of the Cuban revolution, a nucleus of cultural production and the origin of numerous and varied Pan-American cultural initiatives. Revista Casa, a monthly associated with the eponymous institution, was founded in 1960, shortly after the creation of Casa de las Américas, and emerged among other organs and initiatives of the newly founded institution. The journal Casa soon became a central Latin American forum, gathering and exalting the energies and ideas of Latin American intellectuals throughout the Americas. Casa as an intellectual project was overtly political: its first director, Haydée Santamaría, was part of Fidel Castro's insurgent forces in the Sierra Maestra and, like other revolutionaries, would continue

9. I refer to both journals in the past as in this paper I focus mainly on the sixties and seventies, the years when they were both active. However, Revista Casa continues to exist and to be influential and dynamic.

10. The examination of translation in Casa and Marcha is part of a larger study about the translation practice of several influential Latin American and Caribbean periodicals. In this article I focus on the selection of translated materials in these two journals. 
the revolutionary project in the newly structured social and cultural institution. ${ }^{11}$ Moreover, both Casa the institution and Revista Casa were, from their inception, Latin American projects. Casa in fact became-and to an extent continues to be-an influential Latin American cultural space. Among other things, it endeavoured to offer a counterpoint to dominant narratives of culture in Latin American intellectual discourse.

For Revista Casa, translation was the exception more than the rule. However, despite the fact that they were significantly less frequent than non-translated material, translated texts played a central role in the development of Revista Casa, its debates, and the Panamerican scope and area of influence it accomplished to shape from its creation. True to its Latin American scope, it has consistently published texts mostly by Latin American and Caribbean writers and intellectuals, most of which were originally written in Spanish. On average, we can find translated material in one out of every two issues and, when translations are present, the translated contents are, most of the times, less than half of the overall published materials in a given issue. Between 1960 and 2000 Revista Casa featured translations from more than fifteen languages including English, French, Portuguese, Russian, Italian, Chinese, Vietnamese, Romanian, German, Czech, Hungarian, Slovak, Galician, and various Caribbean Creoles (French and English-based). The majority of texts were translated from French, English and Portuguese. Translations from the Portuguese are largely from texts by Brazilian authors.

In Revista Casa we find a significant number of translations of texts by United States authors. These are, almost without exception, texts and statements by civil-rights activists and political radicals and authors committed to social justice-from Martin Luther King to Alice Walker and Toni Morrison. However, the great majority of translations from English are of texts written by authors from Anglophone Africa and the Caribbean. This is also true for French and Creole, which are to a large extent translations of texts by authors from the Americas. In regard to the Caribbean, Casa as an institution, through its decades of cultural programming, its

11. After Santamaría, since 1965 (issue No. 30) and until the end of the twentieth century, the director of Revista Casa was the Cuban intellectual Roberto Fernández Retamar, author of the influential essay "Caliban" (at present Casa's director is Jorge Fornet). 
publishing house, Revista Casa, and most recently in the Centro de Estudios del Caribe, has granted a central position to translations of Caribbean authors. This is one of the distinctive features of Revista Casa vis-à-vis other journals with a Latin American scope. ${ }^{12}$

There is a higher density of translation in special issues devoted to regions where languages other than Spanish were prevalent. For example, in 1970 an entire issue, No. 58, was devoted to the inaugural Pan-African Cultural Festival that had taken place in 1969 in Algiers, and in 1975 issue No. 91 was devoted to the Anglophone Caribbean. These and other special issues included almost exclusively translations. Conspicuous in its near absence is translation from Russian and from any other languages of the entire Soviet bloc. Despite the political relationship between Cuba and the Soviet Union until the end of the eighties, and especially throughout the so-called quinquenio gris or the Grey Years, ${ }^{13}$ the presence of Soviet era texts, and of translations from Russian and from the languages of Eastern Europe, is almost insignificant compared to French, English, Portuguese and even Italian. This suggests that, while organically connected with the political field, the cultural field-if Revista Casa is any index-had its own workings and a measure of autonomy.

There is no evidence of a statement of policy or plan for translation as part of a general editorial practice in Revista Casa. For example, at first translators were not identified, nor was the language of origin of the texts translated; within five years of publication, the presence of translations and translators in Revista Casa became more overt and visible. Translators credits appear, in most cases, at the end of their translation. A significant feature of translation practice in Revista Casa is the fact that the presence of translation in the journal is not limited to the translation of articles, poems, or other stand-alone pieces: the book review section, present in every issue, includes reviews of translations; moreover, the editorial section at the end, entitled "Al pie de la letra"-literally: "verbatim"-where

12. I devote other articles (forthcoming) to the translation praxis of Casa and other Caribbean periodicals (see Guzmán, 2017) and, specifically, to the emphasis of translations from Caribbean sources in Revista Casa. For a discussion of the importance of the Caribbean in Casa de las Américas see also Arencibia, Morejón, and Sanz (2014).

13. The quinquenio gris is a term coined by Cuban literary critic Ambrosio Fornet (2007) to describe government policies in Cuba during a period of higher control over artistic life in Cuba between 1971 and 1976. 
the editorial voice can be felt at its strongest, and one of the sections for which Revista Casa became well-known, integrated fragments of translated texts in practically every issue. These were mostly excerpts of international newspaper articles (e.g., several from Le Monde Diplomatique), often about topics related to Cuba, Cubans abroad, and Cuban cultural policy, as well as to Latin American cultural production (e.g., several pieces documented the internationalization of the so-called Latin American Boom in the seventies). The editorial "voice" positioned itself vis-à-vis the views represented in the excerpt cited: it would either expose the differences between its views and Revista Casa's, or endorse them, in which case translation served to legitimize or support the view of Revista Casa.

\section{Translation in Cuadernos de Marcha (first period)}

The Uruguayan Revista Marcha was founded in 1939 by the renowned intellectual Carlos Quijano. It began as a weekly with various sections, including politics, social science, film, literature, and arts. Some of its collaborators were to become important intellectual figures in the Uruguayan and Latin American intellectual field; among them were well-known authors such as Juan Carlos Onetti, Mario Benedetti, Eduardo Galeano, Ángel Rama. In 1967, Quijano created a sister journal, Cuadernos de Marcha, a monthly that aimed to treat with greater depth the political and conceptual debates that would take place in the weekly. Both the weekly Marcha and the monthly Cuadernos were published continuously in Uruguay until the government closed them in 1974, soon after the military coup. ${ }^{14}$

Marcha had engaged intellectual and political debates of the left in Uruguay since the forties, but it was in the sixties when it embarked more explicitly on an intellectual and political project that identified itself as Latin American. As stated in its editorial, Marcha sought the integration of Uruguay within the "gran patria latinoamericana" [the great Latin American nation], to fight imperialism and to help understand the problems of the so-called Third World, and of the world at large, from an independent perspective underscoring political sovereignity and cultural autonomy.

14. Here the focus is on the primera época or "first period" of Cuadernos, published in Montevideo. The last issue of Marcha was published in 1974. A second period of Cuadernos was later edited from Mexico, where Carlos Quijano was exiled. Currently there is in Uruguay a relatively new weekly, Brecha, which follows the tradition of Marcha. 
In terms of translation practices, between 1967 and 1974, 24 out of 78 issues of Cuadernos included translations. The main languages from which texts were translated were English, French, German, Russian, and Brazilian Portuguese. Similar to Revista Casa, translations covered issues having to do with international relations and conflicts involving the Americas and foreign policies (e.g., Vietnam), civil rights and social justice struggles (e.g., texts by Martin Luther King, CLR James, and others), the 1968 student movements, and an emphasis on texts with a left-wing ideology, various issues included articles on popular education, liberation theology, and texts by Marxist intellectuals from around the world. Among the issues that included the most translations were "El Poder Negro," devoted to the Black Power movement (No. 12, April 1968), one about May 68 and the student movement (No. 15, “Los estudiantes,"July 1968) and “África 69" (No. 28, 1969).

A characteristic feature of translation praxis in the Cuadernos, which created a peculiar narrative effect, was using translated texts from different origins and opposing points of view, leading to a particularly effective form of critical counterpoint. For instance, in a number of issues devoted to the "Church today" [La Iglesia Hoy] in the mid-sixties, translation was employed in order to display opposing views-i.e., texts by liberation theologists were published alongside Italian and Latin texts which represented the viewpoint of the Vatican and the mainstream Church. These translated texts, brought "from a distance," were framed by the editorial voice to emphasize the opposing views and contesting agendas, in so doing further reinforcing the commitment to social justice on the part of those who embraced the liberation theology position, with which Marcha sympathized.

Contrary to the case of Revista Casa, in which translated pieces are often attributed, translation in Cuadernos de Marcha is practically a covert practice. It is evident that, among the issues published in Montevideo, several relied heavily on translations and translators, but this often went unacknowledged. The reader knows the text is a translation because it is by a French or German author, for example—e.g., Sartre, Marx, Marcuse—or because there is indication in the editor's note or some other place in the issue that the text first appeared in a foreign language source. A few issues, such as the first one on the Brazilian dictatorship (No. 37, 1970) and the ones on Israel and on Palestine (No. 42 and 43, 
1970), were assigned to guest editors. In those cases, translation was not mentioned even though these issues relied almost entirely on translations-i.e., they contain "assumed translations" (for a discussion on this concept see Toury, 1995). In the case of one of the issues on Brazil, the editor included, in addition to articles, the testimonies of women who had been victims of torture by the dictatorship. Those testimonies by Brazilian torture survivors appear in Spanish, which means that they must have been translated from Portuguese. One exception, in which the use of translations is more explicit, was the issue on Black Power. In it, although the translations were not individually marked, the editor's introduction indicates the names of the translator of the English texts and of the French texts-it also notes the French-language source from which some of the texts where taken. Not mentioning translators may have been part of a larger editorial policy, as contributors and authors were sometimes not mentioned individually either. Marcha and its Cuadernos presented and framed themselves largely as a collective project.

\section{Translating as a Way of Composing Territorial Imaginaries}

The archive-with its selective quality, its omissions and its silences - is inherently incomplete and fragmentary. While the indepth, comprehensive examination of the translated materials in Revista Casa and Cuadernos de Marcha illuminates several aspects of intellectual vectors of exchange and of the cultural field in the sixties and seventies, it also opens up numerous questions. This ongoing study of the translation praxis of Revista Casa and Cuadernos de Marcha has so far led me to a few provisional observations.

To begin with, the editors and contributors of these journals recognized that they shared a collective cultural and political project. Despite the geographic distance of their origins, the journals and the subjects associated with them were in conversation. Many well-known and influential intellectuals participated in both, among them Eduardo Galeano, Mario Benedetti, Rene Depestre, and Angel Rama. Revista Casa and Marcha were part of a larger intellectual conversation. Their translation practice can only be understood in relation to the larger intellectual project in which it occurs and to the vision that frames it. In both cases translation was part of a project of self-determination. The materials selected for translation, accompanied by other works revolving around the same 
themes or engaging common or current debates and events (e.g., the Vietnam war, to which both Revista Casa and Cuadernos de Marcha devoted entire issues), were in line with the larger narrative and discursive composition, aimed to provide a Latin American counter history and to offer a contrapuntal narrative strategy to Euro-American hegemonic discourse.

Even though these periodicals do not state an explicit and carefully thought-out translation policy, translation is part of their larger editorial vision. Whether practised consistently or employing varying strategies and editorial techniques, translating foreign texts was in tune with the social and intellectual project each sought to advance. Moreover, the editorial team was often actively involved in doing translations. In fact, in Revista Casa the members of the editorial committee translated materials regularly (Roberto Fernández Retamar himself translated numerous pieces, mainly from English and often poetry). In this and other ways the translation praxis appeared to be an extension of the narrative praxis of the journal.

Translation practice exceeds the limits of each individual translated text as it bleeds outside of it and into other texts, genres, and frames that are less recognizable as translations as such. For example, translations or translation fragments appear in lengthy citations, reviews, and significantly, in sections of the journals in which the editorial voice is more clearly present. Translation is intertwined with poetics and also with exegesis - this can be seen wherever translation is used covertly, or in paratextual notes and other apparently less central sections-the clearest case of this translation use is in the already-mentioned editorial section "Al pie de la letra" in Revista Casa. The cultural and political commentary relies heavily on translation.

The selection of English texts translated for inclusion in both is heavily coloured by their anti-imperialist agenda. This can be seen in Revista Casa through the publication of texts by US civil-rights activists and social movement-leaders, which were translated for publication despite the embargo. Translation from English, French, and Creole, favours the translation of intellectual communities that are mostly of the Americas and commonly considered peripheralthis is specifically the case for the French- and English-speaking Caribbean. These journals demonstrate the importance of contextualizing translation practice in order to arrive at conclusions 
regarding individual languages. Rather than viewing them as isolated entities, it is crucial to understand them as organically linked to relations and vectors of exchange, and situated in relation to agents and loci of enunciation and to spaces and territories of contact and relation. It is also imperative to contextualize when it comes to understanding the translators' presence in terms of visibility and invisibility. In the case of Cuadernos de Marcha, translator's names are rarely mentioned. This practice could be read exclusively as part of the traditional omission of the fact of translation and of the presence of translators as active agents. The omissions may be there, but they may also be motivated in part by the fact that, as a collectivist project, Marcha tended to deemphasize individual authorship. Moreover, during its historic-political time, i.e., born in the Southern Cone and active during years of increasing repression leading to long-lasting dictatorships, Marcha was covering pressing subjects about current events in Latin America at the time. Looking at it in temporal-historical terms one can see, on the one hand, a sense of urgency that superseded the establishment of a considered editorial structure; on the other hand, it may even be concluded, specifically in the case of Marcha, that invisibility-in the sense of non-identification - served the purpose of protecting intellectuals from repression under the guise of anonymity (e.g., as in the case of the victims of torture by the Brazilian regime). The scope of each intellectual project goes beyond the journal itself, and so does translation practice. Both Revista Casa and Cuadernos de Marcha were organically ingrained in larger cultural and social projects, linked to revolutionary and progressive movements throughout Latin America and in conversation with social movements around the world. One important function of their translation praxis was serving as one of the strategies of consciousness-raising, toward a goal for social change.

Regarding the question of the specifically Latin American scope and vision of both of these editorial projects, it is clear from the observation of their narrative practices that they did strive to this goal in their contents, including the translations. Both projects are true to their Latin American vision and both have an emancipatory mission that is consciously for and from the Americas. The aspect in which they differ is in the amount of Latin American content being translated in their pages. In the case of Marcha, Latin America is discussed and theorized mainly via ideas 
from intellectuals from the Southern Cone and from a European Left, from which the political project is drawn. The translations are framed in conversation with Latin American thought, but the dialogue, as constructed within the journals' translation praxis, takes place mostly between Spanish-speaking Latin American intellectuals and European ones-with a few exceptions, mostly of content from Brazilian sources. Conversely, in Casa there is a high density of translated content from the Americas, North and South and including, centre-stage, the Caribbean. As such, Casa's translations challenge the traditional directionalities of the Latin American colonial intellectual legacy and aim to produce other, pluridirectional mappings.

Through the years, in the pages of Revista Casa-and in the intellectual praxis of the institution at large-the image of the Americas, and of Latin America in particular, that emerges, is an image of a heterogeneous, multilingual territory and a plural intellectual imagination. Mapping the vectors of exchange that can be traced via translation in Casa we can see a constellation that brings to the fore the languages of the Americas and gives space to plural, vernacular voices. In so doing, the narrative and translation praxis of Casa defies the maps traced by colonial legacies and partakes in a broader decolonial project. Revista Casa establishes an intellectual counterpoint to dominant cultural practices, and creates, poïeticly, transculturally, positing new intellectual territorialities, strengthening and energizing the body of the Americas, and creating the conditions of possibility to imagine the Americas otherwise.

The examination of the translation praxis in Revista Casa and Cuadernos de Marcha demonstrates that, just as the translators and editors of these editorial projects were committed to transformation in their society, the emancipatory value of translation and the ethos of the translators can hardly be evaluated on the textual level alone. Although periodicals can-and at times have been-reduced to materials of the past, at best stored in library archives or cherished by specialized book collectors, and considered as having exclusively historical value, their narrative and translation praxis, continues to emanate and breathe life into the archives that house them. They are organically connected with the historical composition of the Americas and with our present. 


\section{References}

Arencibia, Lourdes, Nancy Morejón and Ileana Sanz (2014). "Foro: Cuba traduce el Caribe" [Forum: Cuba Translates the Caribbean]. Tusaaji: A Translation Review, 3, pp. 88-100.

Crespo, Regina (2010). Revistas en América Latina: proyectos literarios, politicos y culturales [Periodicals in Latin America: Literary, Political, and Cultural Projects]. México, UNAM.

Fornet, Ambrosio (2007). "El Quinquenio Gris: revisitando el término" [The Grey Years: Revisiting the Term]. Casa de las Américas, 246, pp. 3-16.

Foucault, Michel (1980). Power/Knowledge: Selected Interviews and Other Writings. Trans. C. Gordon, L. Marshall, J. Penham, K. Soper. New York, Pantheon.

Guzmán, María Constanza (2013a). "Ángel Rama y la traducción como praxis y experiencia americana" [Ángel Rama’s Work and Translation as a Praxis and Experience of the Americas]. In I. Fenoglio, R. Díaz de la Sienra and M. Quijano, eds. La tradición teórico-critica en América Latina: mapas y perspectivas. México, Bonilla Artigas Editores, pp. 57-71.

Guzmán, María Constanza (2013b). "Translation North and South: Composing the Translator's Archive." TTR, 26, 2, pp. 171-191.

Guzmán, María Constanza (2017). "E1 Caribe se traduce: la traducción como praxis descolonial en las revistas Tropiques, Bim, y Casa de las Américas." Mutatis Mutandis, 10, 1, pp. 167-181.

Elizalde, Lydia (2008). Revistas culturales latinoamericanas (1920-1960) [Latin American cultural periodicals (1920-1960)]. México, UAEM.

Elizalde, Lydia (2010). Revistas culturales latinoamericanas (1960-2008). [Latin American cultural periodicals (1960-2008)]. México, UAEM.

Franco, Jean (2002). The Decline and Fall of the Lettered City: Latin America in the Cold War. Cambridge, Harvard University Press.

González Echevarría, Roberto (1990). Myth and Archive: A Theory of Latin American Narrative. New York, Cambridge University Press.

Liu, Lydia H. (1999). Tokens of Exchange: The Problem of Translation in Global Circulations. Durham, Duke University Press.

Moraña, Mabel and Horacio Machín, eds. (2003). Marcha y América Latina [Marcha and Latin America]. Pittsburgh, Biblioteca de América, IILI, Universidad de Pittsburgh.

Peirano Basso, Luisa (2001). Marcha de Montevideo y la formación de la conciencia latinoamericana a través de sus cuadernos [Montevideo's Cuadernos de Marcha and the configuration of a Latin American consciousness]. Buenos Aires, Javier Vergara Ed. 
Pratt, Mary Louise (1992). Imperial Eyes: Travel Writing and Transculturation. London and New York, Routledge.

Quijano, Aníbal (2000). “Coloniality of Power, Eurocentrism, and Latin America." Nepantla: Views from South, 1, 3, pp. 533-580.

Rama, Ángel (1984). La ciudad letrada [The Lettered City]. Hanover, Ediciones del Norte. [2002]

Rama, Ángel (1985). La transculturación narrativa en América [Narrative Transculturation in Latin America]. México, Siglo Veintiuno.

Rama, Ángel (1986). The Lettered City. Trans. John Charles Chasteen. Durham, Duke University Press.

Rama, Ángel (2012) Writing across Cultures: Narrative Transculturation in Latin America. Trans. David Frye. Durham, Duke University Press.

Sarlo, Beatriz (1999). La máquina cultural: maestras, traductores y vanguardistas [The cultural machine: woman educators, translators, and avant-gardists]. Buenos Aires, Seix Barral.

Sosnowski, Raúl (1999). La cultura de un siglo: América Latina en sus revistas [A Century's Culture: Latin America in its Journals]. Madrid, Alianza Editorial.

Toury, Gideon (1995). “The Notion of 'Assumed Translation' - An Invitation to a New Discussion." In H. Bloemen, E. Hertog and W. Segers, eds. Letterlijkheid, Woordelijheid/Literality, Verbality). Antwerpen/Harmelen, Fantom, pp. 135-147.

Willson, Patricia (2004). La constelación del Sur. Traductores y traducciones en la literatura argentina del siglo $X X$ [The Constelation of Sur: Translators and Translations in Twentieth Century Argentine Literature]. Buenos Aires, Siglo XXI.

\section{Periodicals surveyed}

Revista Casa de las Américas. Casa de las Américas. La Habana, Cuba. Issues 1960-2000.

Cuadernos de Marcha. Montevideo, Uruguay. Issues 1967-1974.

María Constanza Guzmán School of Translation - Department of Hispanic Studies Glendon College, York University 2275 Bayview Ave. Toronto (Ontario) M4N 3M6 CANADA mguzman@glendon.yorku.ca 